\title{
A Correlative Study of Sunflower Seed Vigor Components as Related to Genetic Background
}

\author{
Marine Saux ${ }^{1}$, Benoît Bleys ${ }^{2}$, Thierry André ${ }^{2}$, Christophe Bailly ${ }^{1,+}+(0)$ and \\ Hayat El-Maarouf-Bouteau 1,*,+ \\ 1 Sorbonne Université, CNRS, Laboratoire de Biologie du Développement, F-75005 Paris, France; \\ marine.saux31@gmail.com (M.S.); christophe.bailly@sorbonne-universite.fr (C.B.) \\ 2 Soltis, 6 chemin de Panedautes, 31700 Mondonville, France; benoit.bleys@soltis-research.com (B.B.); \\ thierry.andre@soltis-research.com (T.A.) \\ * Correspondence: hayat.bouteau@sorbonne-universite.fr; Tel.: +33-1-44-27-59-25 \\ + These authors contribute equally.
}

Received: 14 February 2020; Accepted: 18 March 2020; Published: 20 March 2020

\begin{abstract}
Seed vigor is an important trait that determines seed performance in the field, which corresponds to seed germination rate and seedling establishment. Previous works brought helpful equations to calculate several parameters allowing vigor characterization. In this work we used base water potential $(\mathrm{Hb})$, base temperature $(\mathrm{Tb})$ and seed lot $(\mathrm{Ki})$ constants to characterize the vigor of 44 sunflower seed lots. Contrasting responses to water or temperature stress and storage potential were recorded within this population, the most interesting being the opposite responses between $\mathrm{\Psi b}$ and $\mathrm{Ki}$. The genotypes that were resistant to water stress presented low ability for storage and vice versa. Furthermore, $\Psi \mathrm{b}$ and Ki presented narrow ranges while $\mathrm{Tb}$ showed important variability within the 44 genotypes. The analysis of the whole dataset showed that these constants are not correlated to each other or to the seed size, suggesting that genetic background is the most important determining factor in seed performance. Consequently, vigor characterization of genotypes is needed in the crop selection process in order to optimize agricultural productivity.
\end{abstract}

Keywords: seed; vigour; genotype

\section{Introduction:}

Seed germination, vigor and viability describe different aspects of the quality of a seed population, and these three aspects need to be addressed together to understand the overall quality of a seed lot. Therefore, results of seed germination tests must be analyzed together with results of seed vigor tests in order to differentiate seed lots of acceptable germination [1]. Germination is defined as the protrusion of the radicle through the seed envelopes in favorable conditions. However, germination environments can be far from favorable and can impose stresses on seeds, which can delay or prevent germination. The standard germination assay performed in the laboratory is thus a poor predictor of emergence in non-optimal environments. Seed vigor reflects properties of a seed to germinate in a wide range of environmental conditions. It can be defined as the capacity of seeds to lead to rapid and homogenous seedling emergence and stand establishment [2]. Since crop yield is a function of plant density, seed vigor can influence crop yield by its effects on emergence. High seed vigor may increase crop yield [1]. If seed quality only altered emergence percentage, then growers could overcome such effects by adjusting sowing rates. However, in practice, seed quality is affected by the seedbed environment, which make it is difficult to adjust and predict seed sowing rates [3]. At last, seed viability refers to whether or not a seed contains any metabolically active tissues and enzymes capable of sustaining living plant cells. 
When seed environmental conditions are close to optimum at the time of sowing, field emergence can correlate with germination test results. However, such conditions are not often encountered in practice, and field conditions are often sub-optimal, which may lead to different field performance depending on the vigor status of the seed lot. This may cause difference in emergence level, rate and growth uniformity and sometimes lower vegetative and reproductive yield. Thus, high vigor seed lots are expected to perform better under environmentally stressed conditions than low vigor seed lots, even if standard germination test results can be comparable (International Seed Testing Association (ISTA)) [4]. Since then, the ISTA [4,5] brought a more specific definition that takes into account not only those properties that determine the activity and level of performance of seed lots of acceptable germination in a wide range of environments but also the performance after storage.

Many environmental factors influence germination, temperature $(T)$ and water potential $(\psi)$ being the most critical $[6,7]$. The thermal time $\left(\theta_{\mathrm{T}}\right)$ approach has been used to characterize the time to germination at different temperatures and, by analogy, the hydrotime describes the relationship between $\psi$ and seed germination [8]. Mathematical models describing germination patterns in response to $\mathrm{T}$ and $\psi$ have been developed (discussed in [9]).

The genetic basis of seed vigor has been established, although it is poorly understood [10]. In the last decades, molecular aspects of seed dormancy and germination have been reported in different species (for review [11-13]) and in sunflower in particular [14-17]. Several genes have been related to seed vigor [18-20], but, they can hardly be used as vigor genetic markers. The quantitative trait loci (QTL) approach allows the identification of loci that influence seed vigor in Brassica oleracea, such as speed of germination (SOG1), which contains two genes related to abscisic acid that influence negatively the speed of germination [21-23]. Speed of germination is nevertheless one property among others in the characterization of seed vigor, which is a complex trait, and its proper evaluation is highly challenging. In fact, the causes of difference in seed vigor can come from the genotype, the nutrition and growth conditions of the mother plant, the physiological maturity of the seed at harvest, the physical handling of the seed during processing, seed moisture content and the temperature during storage [10].

In this paper, we investigated sunflower (Helianthus annuus) seed vigor in 44 genotypes produced simultaneously in the same field in order to overcome the differences due to the environment. Seed germination was assessed in response to water and temperature stress and after accelerated ageing, and the corresponding constants and their relevance in seed vigor were determined. Our objectives were to decipher the relationship between the various components of seed vigor and to determine whether they are controlled by the genetic background.

\section{Results}

\subsection{Effect of Water Stress}

Several intensities of water stress (from -0.2 to $-1.2 \mathrm{MPa}$ ) were applied to the seeds of 44 genotypes using PEG solutions instead of water $(0 \mathrm{MPa})$ during germination at $20^{\circ} \mathrm{C}$, and kinetics of germination were recorded (Table S1). As an example, Figure 1 shows contrasting germination behavior of the 2 genotypes SOLQUA-160 (Figure 1A) and SOLQUA-165 (Figure 1B). At $20{ }^{\circ} \mathrm{C}$, seeds of both genotypes fully germinated within $3 \mathrm{~d}$ at $20^{\circ} \mathrm{C}$ (Figure 1). Decreasing water availability by increasing PEG concentrations in the imbibition media had an inhibitory effect on seed germination. Seeds of SOLQUA-165 were more sensitive to water stress as their germination could not reach $100 \%$ when water stress was applied even at low PEG concentrations. At high stress (-1.2 MPa), seeds of SOLQUA 165 were unable to germinate (Figure 1B), whereas seeds of SOLQUA-160 reached at least $80 \%$ of germination (Figure 1A). 

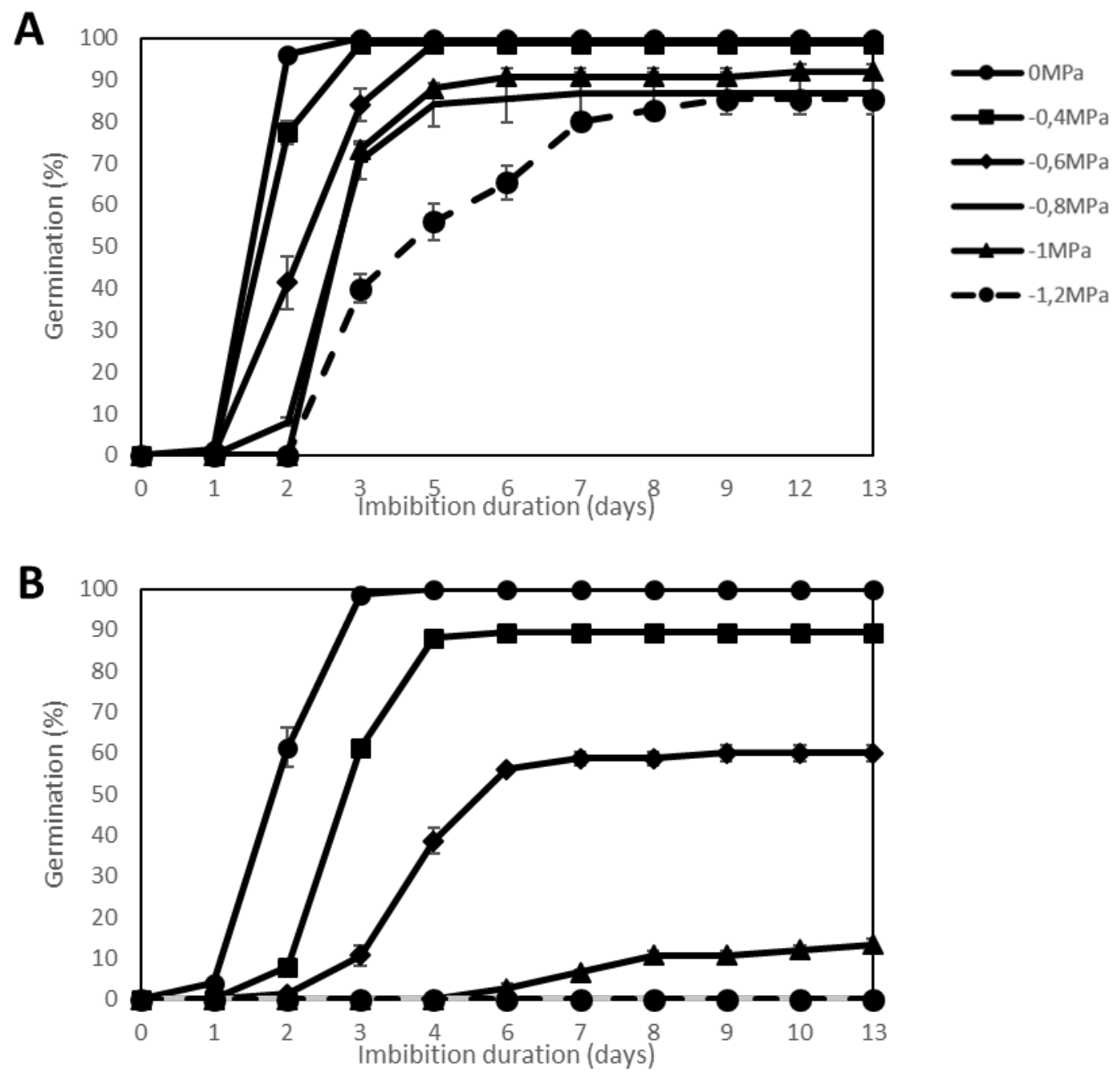

Figure 1. Germination curves of 2 sunflower genotypes, Helianthus annuus sp. SOLQUA-160 (A) and SOLQUA-165 (B) Water stress (-0.4 MPa; $-0.6 \mathrm{MPa} ;-0.8 \mathrm{MPa} ;-1 \mathrm{MPa} ;-1.2 \mathrm{MPa})$ was applied during germination at $20^{\circ} \mathrm{C}$ in comparison to the control on water $(0 \mathrm{MPa})$.

\subsection{Effect of Temperature Stress}

Several temperatures $\left(5,10,15,20,25,30\right.$ and $\left.35^{\circ} \mathrm{C}\right)$ were applied to the seeds of the 44 genotypes during germination tests on water (Table S1). Figure 2, comparing germination percentages of seeds of SOLQUA-160 and SOLQUA-165, shows that both genotypes can germinate to $100 \%$ between 10 and $25^{\circ} \mathrm{C}$, which correspond to optimal temperatures for sunflower seed germination. However, for high temperatures such as 30 and $35^{\circ} \mathrm{C}$ SOLQUA-165 seed germination was reduced to less than $40 \%$ and for low temperature $\left(5^{\circ} \mathrm{C}\right)$, their germination was arrested (Figure 2B). In contrast, even if the rate of germination of $S O L Q U A-160$ seeds was lowered at $5{ }^{\circ} \mathrm{C}$, their final germination percentage reached $100 \%$ at all temperatures tested (Figure 2A). 

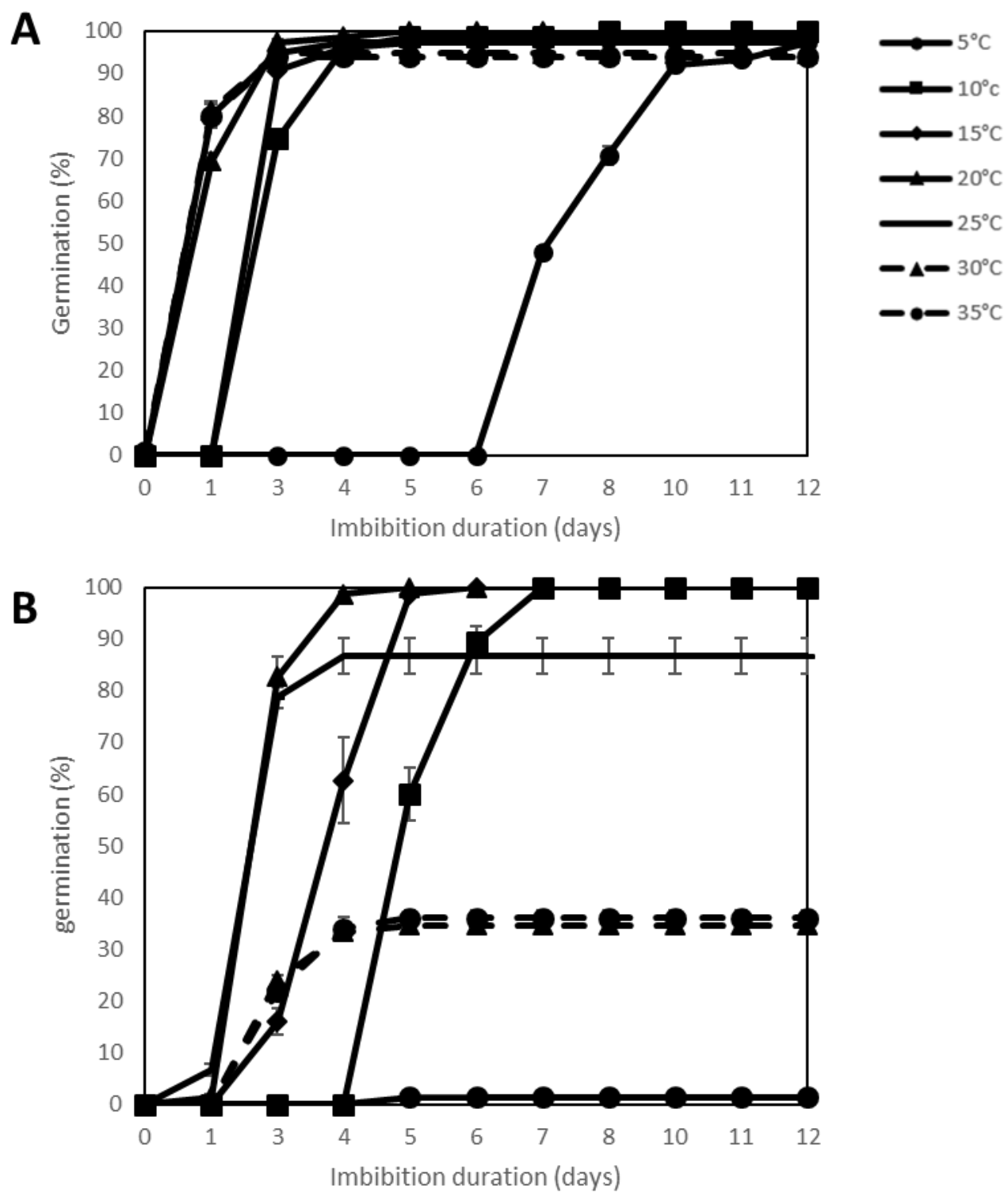

Figure 2. Germination curves of 2 sunflower genotypes, Helianthus annuus sp. SOLQUA-160 (A) and SOLQUA-165 (B) Temperature stress $\left(5,10,15,25,30\right.$ and $\left.35^{\circ} \mathrm{C}\right)$ was applied during germination in comparison to the control on water at $20^{\circ} \mathrm{C}$.

\subsection{Effect of Accelerated Ageing}

Accelerated ageing $\left(100 \% \mathrm{RH}\right.$ and $\left.45{ }^{\circ} \mathrm{C}\right)$ was applied for $1,3,4$ or 7 days as compared to the control 0 , which corresponded to non-aged seeds. This treatment first decreased seed germination speed then seed viability as estimated by the final germination percentage after $11 \mathrm{~d}$ at $20^{\circ} \mathrm{C}$ (Figure 3 ). Figure 3 shows that seeds of SOLQUA-160, which were quite tolerant to water and temperature stresses, were more sensitive to ageing when compared to seeds of SOLQUA-165. In fact, 3 or 5 days of treatments decreased germination percentages of seeds of SOLQUA-160 to around 50 and $20 \%$, respectively, while SOLQUA-165 seeds germinated to 95 and $82 \%$ in the same conditions (Figure 3). 
A

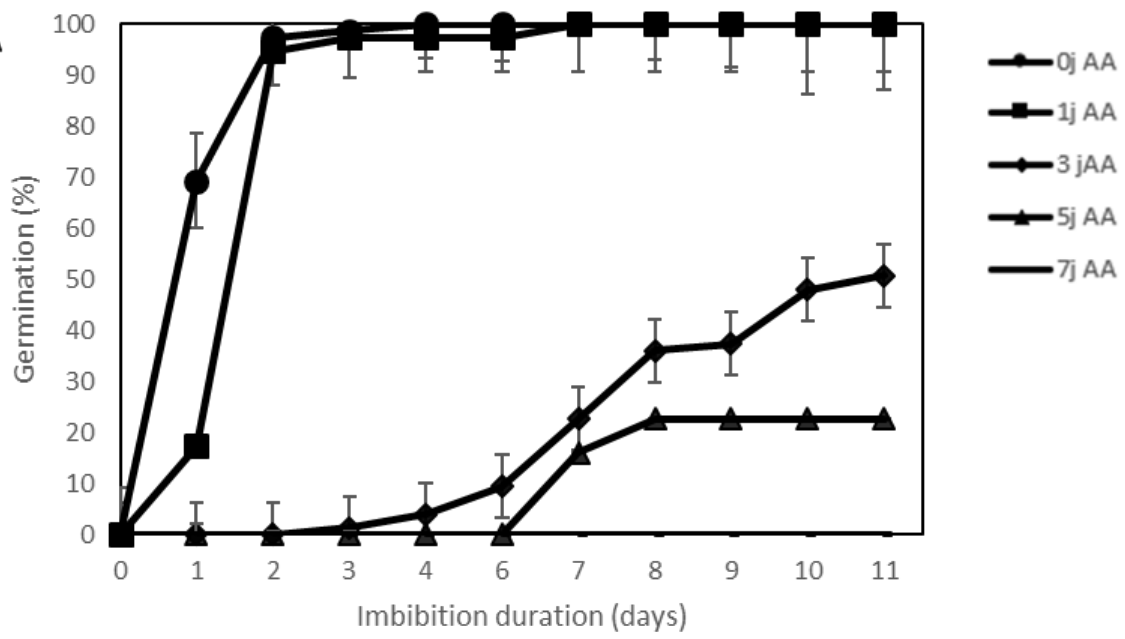

B

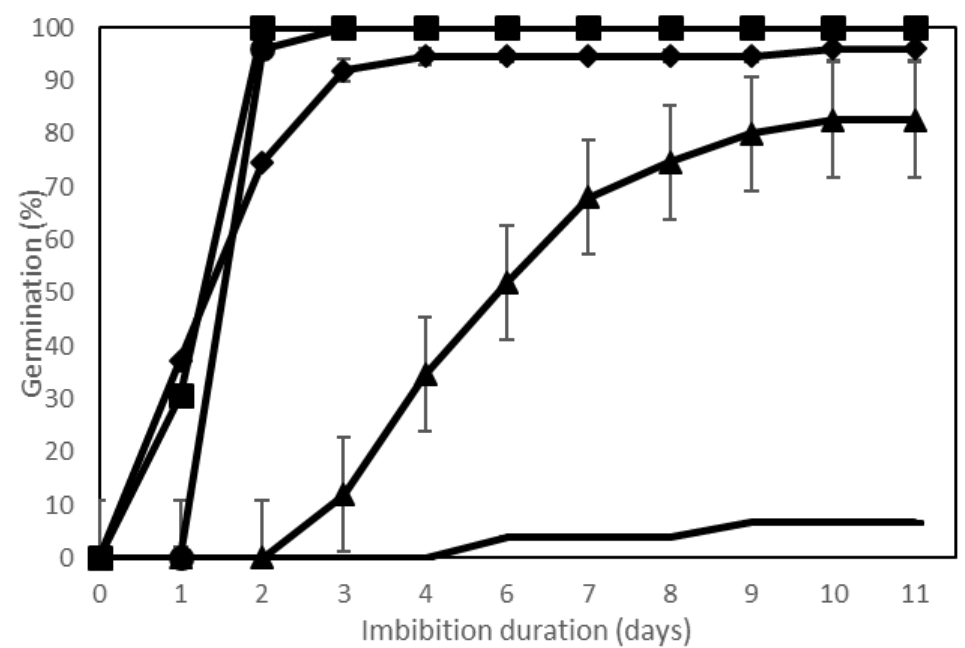

Figure 3. Germination curves of 2 sunflower genotypes, Helianthus annuus sp. SOLQUA-160 (A) and SOLQUA-165 (B) Accelerated ageing (AA) was applied for 1, 3, 4 or 7 days (as compared to the control 0 , which corresponded to non-aged seeds); germination tests were then performed on water at $20{ }^{\circ} \mathrm{C}$.

\subsection{Determination of Seed Vigor Constants}

Using the mathematic models described by Ellis and Roberts [24] and Bradford [8], we calculated the seed vigor parameters, i.e., base water potential $(\mathrm{\Psi b})$, base temperature $(\mathrm{Tb})$ and the viability constant (Ki) of the 44 genotypes (Table 1$)$. Three cardinal temperatures corresponding to the base $\left(T_{b}\right)$, optimum $\left(T_{\mathrm{o}}\right)$ and maximum temperatures $\left(T_{\mathrm{c}}\right)$ were determined for germination [25]. They are useful to determine the best planting period for a given specie. We focused on $\mathrm{Tb}$ because sunflower seed vigor was expressed at low temperatures, and the purpose of the present study was to characterize germination parameters in suboptimal conditions of germination. $\mathrm{Tb}$, which represented the lower thermal limit for seed germination, ranging from negative values as low as $-3{ }^{\circ} \mathrm{C}$ to $5.62{ }^{\circ} \mathrm{C}$ according to the genotype (Table 1). Variability of seed response to water stress was shown by $\Psi \mathrm{b}$ values, which also differed markedly among genotypes (Table 1). Ki value represented the initial quality of the seedlot and was determined using germination values after accelerated ageing; the higher it is, the higher is the initial quality [24]. As for the other vigor constants studied here, our analysis highlighted a large variability of $\mathrm{Ki}$ values among seed lots; they ranged from 4.2 to 1.1 (Table 1). In order to analyze the correlation that may exist between $\Psi \mathrm{b}, \mathrm{Tb}$ and $\mathrm{Ki}$, corresponding values were analyzed using the Pearson correlation method. Table 2 shows very low $R^{2}$ (between 0.035 and 0.058 ), indicating that these parameters were not correlated to each other (Table 2). 
Table 1. Seed vigor parameters, base water potential $(\Psi \mathrm{b}, 50 \%)$, base temperature $(\mathrm{Tb})$ and viability constant $(\mathrm{Ki})$ of seeds of the 44 genotypes. nd: non determined.

\begin{tabular}{|c|c|c|c|c|}
\hline Number & Genotypes & $\Psi \mathrm{b}(50 \%)(\mathrm{MPa})$ & $\mathrm{Tb}\left({ }^{\circ} \mathrm{C}\right)$ & Ki \\
\hline 1 & SOLQUA-003 & -1.066 & 3.07 & 2.0823 \\
\hline 2 & SOLQUA-006 & -1.2284 & 2.15 & 2.3716 \\
\hline 3 & SOLQUA-007 & -1.1135 & 1.58 & 2.3209 \\
\hline 4 & SOLQUA-011 & -0.9311 & 4.53 & 2.0814 \\
\hline 5 & SOLQUA-015-3 & -0.9404 & 4.17 & 2.4945 \\
\hline 6 & SOLQUA-020 & -1.0896 & 3.62 & 1.6434 \\
\hline 7 & SOLQUA-023 & -0.8251 & 3.06 & 0.7898 \\
\hline 8 & SOLQUA-024 & -0.9446 & 1.72 & 1.9408 \\
\hline 9 & SOLQUA-028 & -0.9856 & 1.27 & 2.3179 \\
\hline 10 & SOLQUA-030 & -1.0049 & -0.9 & 2.034 \\
\hline 11 & SOLQUA-031 & -2.217 & 4.39 & 2.169 \\
\hline 12 & SOLQUA-037 & -1.0511 & 2.4 & 1.8161 \\
\hline 13 & SOLQUA-037-2 & -1.1699 & -0.36 & 2.0397 \\
\hline 14 & SOLQUA-040 & -2.0158 & 2.27 & 1.0646 \\
\hline 15 & SOLQUA-047 & -1.1548 & 5.42 & 2.0977 \\
\hline 16 & SOLQUA-048 & -0.9483 & 1.5 & 1.8038 \\
\hline 17 & SOLQUA-050 & -0.9966 & 2.93 & 1.6187 \\
\hline 18 & SOLQUA-055 & -1.1191 & 0.05 & 2.6992 \\
\hline 19 & SOLQUA-056-3 & -1.1189 & 0.79 & 1.8438 \\
\hline 20 & SOLQUA-056-4 & -1.1355 & -0.86 & 2.0945 \\
\hline 21 & SOLQUA-057 & -1.1903 & 1.23 & 1.2352 \\
\hline 22 & SOLQUA-068-5 & -1.6805 & 3.67 & 1.4013 \\
\hline 23 & SOLQUA-073 & -0.966 & 3.76 & 1.9841 \\
\hline 24 & SOLQUA-075 & -0.9354 & -3.44 & 3.2565 \\
\hline 25 & SOLQUA-088 & -1.1602 & 4.08 & 2.9622 \\
\hline 26 & SOLQUA-096 & -1.2488 & 5.33 & 2.7511 \\
\hline 27 & SOLQUA-107 & -1.0686 & 2.38 & 2.3946 \\
\hline 28 & SOLQUA-109 & -1.1588 & 2.57 & 3.6534 \\
\hline 29 & SOLQUA-110 & -1.1102 & 2.42 & 1.1141 \\
\hline 30 & SOLQUA-110-2 & -1.5864 & 1.69 & nd \\
\hline 31 & SOLQUA-113 & -0.9967 & 2.86 & 2.4624 \\
\hline 32 & SOLQUA-114 & -0.9953 & 3.39 & 2.1343 \\
\hline 33 & SOLQUA-123 & -1.2608 & 3.33 & 2.5701 \\
\hline 34 & SOLQUA-127 & -1.2095 & 2.64 & 0.4968 \\
\hline 35 & SOLQUA-132 & -0.6323 & 3.4 & 0.6833 \\
\hline 36 & SOLQUA-133 & -1.3559 & 2.95 & 2.373 \\
\hline 37 & SOLQUA-138 & -1.2303 & 1.67 & 2.3454 \\
\hline 38 & SOLQUA-143 & -1.3089 & 1.78 & 1.7256 \\
\hline 39 & SOLQUA-147 & -1.244 & 2.29 & 1.8077 \\
\hline 40 & SOLQUA-148 & -1.1306 & -3.3 & 2.6047 \\
\hline 41 & SOLQUA-160 & -3.1991 & 3.35 & 1.1666 \\
\hline 42 & SOLQUA-165 & -0.7507 & 2.5 & 4.2442 \\
\hline 43 & SOLQUA-168 & -1.6257 & 5.62 & 1.4051 \\
\hline 44 & SOLQUA-169 & -1.094 & 2.64 & 1.9944 \\
\hline
\end{tabular}


Table 2. Correlation between $\Psi \mathrm{b}$, Tb and $\mathrm{Ki}\left(\mathrm{R}^{2}\right)$.

\begin{tabular}{cccc}
\hline Variables & $\mathbf{\Psi b} \mathbf{( 5 0} \%)(\mathbf{M P a})$ & $\mathbf{T b}\left({ }^{\circ} \mathbf{C}\right)$ & $\mathbf{K i}$ \\
\hline$\Psi b(50 \%)(\mathrm{MPa})$ & $1(\mathrm{p}=0)$ & $0.035(\mathrm{p}=0.226)$ & $0.058(\mathrm{p}=0.116)$ \\
\hline $\mathrm{Tb}\left({ }^{\circ} \mathrm{C}\right)$ & $0.035(\mathrm{p}=0.226)$ & $1(\mathrm{p}=0)$ & $0.036(\mathrm{p}=0.218)$ \\
\hline $\mathrm{Ki}$ & $0.058(\mathrm{p}=0.116)$ & $0.036(\mathrm{p}=0.218)$ & $1(\mathrm{p}=0)$ \\
\hline
\end{tabular}

We next performed a principal component analysis (PCA) using the seed vigor constants, which permitted clusterization of the genotypes (Figure 4, Table 3). From this analysis, thresholds values of $\Psi \mathrm{b}$ of $-1.1 \mathrm{MPa}$ and of Ki of 1.5 were determined. Tolerant seed lots to water stress displayed a $\Psi \mathrm{b}<-1.1$ and seeds of high initial quality that may be tolerant for storage of $\mathrm{Ki}>1.5$. The analysis allowed the distribution of genotypes with a high PCA percentage $(74,68 \%)$ in seven clusters corresponding to marked resistance or sensitivity to one or several stresses (Figure 4, Table 3). The cluster 5 contained an important number of genotypes (17), which did not show a marked response to extreme conditions (Table 3). In the other clusters, genotypes displayed contrasted responses. For example, cluster 6 regrouped genotypes that presented high initial quality, tolerance to low temperature and sensitivity to water stress, while cluster 7 included those that presented the same responses but were also sensitive to high temperatures. Interestingly, these clusters of high initial quality were sensitive to water stress when clusters from 1 to 4 grouped seed lots of low initial quality that were tolerant to water stress (Table 3). On the other hand, a very small number of genotypes were represented in cluster 1 and 7 (Table 2). However, in these clusters one can find the interesting genotypes presented earlier, namely SOLQUA-160 in the cluster 1 and SOLQUA-165 in the cluster 7 (Figures 1-3); i.e., in two opposite sides of the PCA (Figure 4). Furthermore, the seed lots of high and low 1000 SW were represented in all the clusters without distinctive distribution (Table 3).

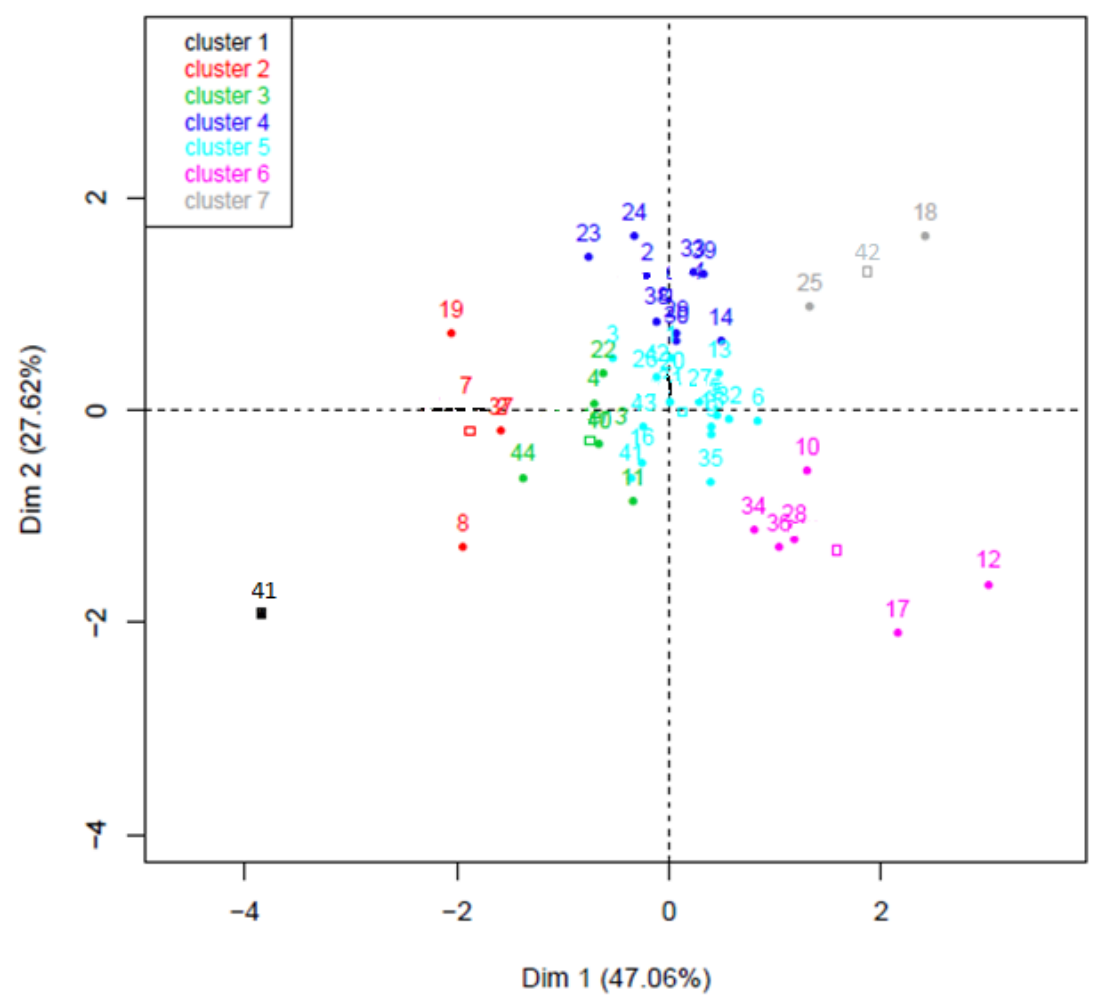

Figure 4. Hierarchical clustering on principal components analysis using seed trait parameters $\Psi \mathrm{b}, \mathrm{Tb}$ and $\mathrm{Ki}$ of the 44 genotypes. Genotypes are represented by numbers, according to Table 1. 
Table 3. Description of genotypes belonging to the different clusters; $1000 \mathrm{SW}$ corresponds to the weight of 1000 seeds $(\mathrm{g})$.

\begin{tabular}{|c|c|c|c|c|}
\hline $\begin{array}{l}\text { Cluster } \\
\text { Number }\end{array}$ & Description of Seed Lot Response & $\begin{array}{l}\text { Number of } \\
\text { Genotypes }\end{array}$ & $\begin{array}{c}\text { Number of } \\
\text { Genotypes Whose } \\
1000 \text { SW }>50\end{array}$ & $\begin{array}{c}\text { Number of } \\
\text { Genotypes Whose } \\
1000 \mathrm{SW}<50\end{array}$ \\
\hline 1 & $\begin{array}{l}\text { Tolerant to high temperatures } \\
\text { Tolerant to water stress } \\
\text { Low initial quality }\end{array}$ & 1 & 0 & 1 \\
\hline 2 & $\begin{array}{l}\text { Tolerant to low temperatures } \\
\text { Tolerant to water stress } \\
\text { Sensitive to high temperatures } \\
\text { Low initial quality }\end{array}$ & 4 & 2 & 2 \\
\hline 3 & $\begin{array}{l}\text { Tolerant to water stress } \\
\text { Low initial quality }\end{array}$ & 6 & 2 & 4 \\
\hline 4 & $\begin{array}{c}\text { Sensitive to low or high temperatures } \\
\text { Tolerant to water stress } \\
\text { Low initial quality }\end{array}$ & 8 & 5 & 3 \\
\hline 5 & None & 17 & 11 & 6 \\
\hline 6 & $\begin{array}{l}\text { Tolerant to low temperature } \\
\text { Sensitive to water stress } \\
\text { High initial quality }\end{array}$ & 6 & 5 & 1 \\
\hline 7 & $\begin{array}{l}\text { Tolerant to low temperature } \\
\text { Sensitive to water stress } \\
\text { Sensitive to high temperatures } \\
\text { High initial quality }\end{array}$ & 2 & 0 & 2 \\
\hline
\end{tabular}

Lastly, in order to analyze the impact of each stress (temperature, water and ageing) on the 44 genotypes, we displayed the data sets of $\mathrm{Ki}, \mathrm{Tb}$ and $\Psi \mathrm{b}$ as a boxplot to show the frequency distribution of the data (Figure 5). Figure 5 shows the small variability of $\mathrm{Ki}$ and $\mathrm{\Psi b}$ values as shown by the width of the corresponding boxes, even though there are some outliers. Tb, however, showed important variability within the 44 genotypes (Figure 5).

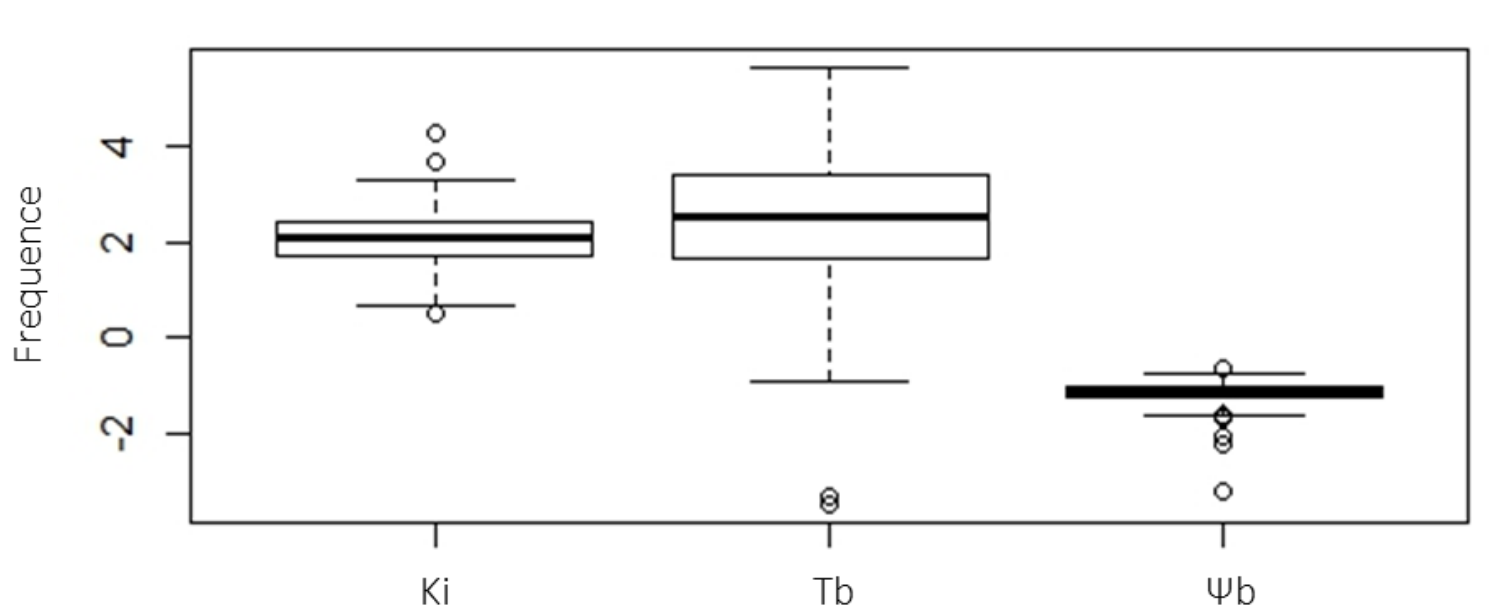

Figure 5. Boxplot presentation of frequency statistical analysis of $\Psi \mathrm{b}, \mathrm{Tb}$ and $\mathrm{Ki}$ values of the 44 genotypes.

\section{Discussion}

In optimal conditions (germination in water at $20^{\circ} \mathrm{C}$ ), seeds of the 44 sunflower genotypes studied here were able to germinate to $100 \%$ (Table S1). These conditions nevertheless rarely correspond to those encountered in the field where temperature and water potential can vary continuously. When subjected to water stress, temperature stress or ageing treatment, seeds show different capacities 
to face one or several stresses. This fact was well illustrated by germination tests of SOLQUA 160 and SOLQUA 165 seeds, which presented contrasting responses to stress conditions (Figures 1-3).

To study the importance of each component of seed performance (resistance to water stress, temperature stress and ageing), $\Psi \mathrm{b}, \mathrm{Tb}$ and $\mathrm{Ki}$ were calculated and analyzed. This analysis allowed a fine characterization of the 44 genotypes, which can be useful for the breeder, as seed vigor has an economic impact for sale but also for seed multiplication [10]. It is worth noting that these parameters can be used to determine a threshold for genotype classification as sensitive or resistant to water stress or low or high initial quality, which is more complicated for temperature response as seed performance can concern low or high temperatures. Using these parameters, further characterization of these 44 seed lots has been performed using PCA (Figure 4). The clustering allowed classification based on seed lot response to temperature or water stresses and initial quality (Table 3). Seventeen out of 44 (cluster 5) seed lots did not show marked tolerance or sensitivity to one or more vigor parameters suggesting that more than $38 \%$ of these selected lines, which are representative of genetic variability within Soltis, did not display important vigor. Clusters 2, 3 and 4 contain genotypes (18/44) presenting low initial quality but good tolerance to water stress at the same time (Tables 1 and 3). The cluster 6 is represented by six genotypes that are classified as tolerant to low temperature and sensitive to water stress with high initial quality (Table 3). Therefore, it is worth noting that tolerance to water stress is associated with low initial quality and vice versa in all genotypes subjected to non-optimal conditions. Regarding the response to temperature, the 44 seed lots present a wide range of $\mathrm{Tb}$ as shown by the box plot analysis (Figure 5). Castillo-Lorenzo et al. [26] have reported that Tb range can be narrow in five H. annuus genotypes that differ in their flowering time and seed oil composition without correlation with seed oil content. In our study, no correlation was found either between $\mathrm{Tb}$ and the other vigor parameters (Table 2), or with seed oil content (data not shown), unlike Gonzales Belo et al. [27], who reported contradictory findings. Ki, calculated using accelerated ageing treatments, can also be used to compare seed lots for their germination performance after storage [25]. Seed initial quality determination being closely related to seed response to high temperature and humidity, it can be assumed that the Ki takes into account the sensitivity to temperature out of context of accelerated ageing; however, one can notice that initial quality or water stress are not necessarily related to response to high temperatures. However, tolerance to low or high temperature represents important information for optimization of sunflower cultivation (Table 3).

Among the 19 genotypes that are tolerant to water stress with high initial quality (clusters 1 to 4 ), 9 have a 1000 SW $>50$ (high) and 10 have a 1000 SW < 50 (low) (Table 3). In the opposite category (clusters 5 and 6), the proportion of high and low 1000 SW is 5 vs. 3, respectively (Table 3 ). In the literature, the correlation between seed size or weight and vigor is controversial even though seed size is generally positively correlated with vigorous seedlings and field performance [28]. Previous works on wheat have shown that grain weight or size had no significant effect on germination $[29,30]$, while other papers have reported that seed size was correlated with final seed germination and vigorous seedlings [31,32]. In sunflower it has been shown that the effect of seed size was significant on germination percentage, the germination of large seeds being less important [33,34]. Our results show that there is no correlation between vigor parameters and seed weight in sunflower. Among the 44 genotypes, maintainers (23/44) had high 1000 SW (>50) and restorers (21/44) had mostly low 1000 SW (only 3 had a 1000 SW > 50) (B and R lines, respectively, Table S1). Such difference can be explained by the fact that maintainer and restorer lines belong to 2 genotype groups corresponding to plants characterized by one or several capitula, respectively (Soltis personal data), suggesting that the size is correlated to the genotype but not to vigor parameters.

Based on genetic distance (Soltis personal data), within each cluster, the closer the genotypes, the closer are their values of vigor parameters. For example, in cluster 2, SOLQUA-168 (R) and SOLQUA-068-5 (R), which are more closely related with each other than with SOLQUA-031 (B), had almost the same $\Psi \mathrm{b}(-1.6)$ and $\mathrm{Ki}(1.4)$ values, while SOLQUA-031 had a $\Psi \mathrm{b}$ of -2.2 and a $\mathrm{Ki}$ of 2.1 ( $\mathrm{Tb}$ was variable but high for all of them). On the other hand, even if some closely related 
genotypes belonged to different clusters, they could have close $\Psi \mathrm{b}$ and Ki values, such as SOLQUA-68-5 (cluster 2) and SOLQUA-110 (cluster 3) that displayed $\Psi \mathrm{b}$ and Ki values of $-1.6,1.4$ and $-1.1,1.1$, respectively (Table 1 and Table S1). Less frequently, some closely related genotypes may have different $\Psi \mathrm{b}, \mathrm{Tb}$ and $\mathrm{Ki}$, such as SOLQUA-132 and SOLQUA-133 (Table 1 and Table S1), indicating that genetic variation, as small as it may be, can induce physiological changes, especially when characterizing vigor, which encompasses many physiological processes. In fact, to meet all the criteria, the seed must possess the mechanisms of tolerance to water and thermal stress in addition to having mechanisms of protection against ageing. This demonstrates that genotype characterization with vigor parameters is definitely necessary to make the best selection.

Controversial findings about the correlation between seed traits, such as seed size or oil composition, and vigor parameters highlight the important part of the genetics that can be, in addition, significantly influenced by the environment (temperature, water and oxygen) from fertilization to seedling emergence [10]. Being unable to control the environmental conditions, it is important to have relevant tests to predict seed performance. Here we show that sunflower seeds display contrasting responses to water stress and seed initial quality. Consequently, $\Psi \mathrm{b}$ and Ki may represent the parameters of importance in relation to seed response to unfavorable environmental conditions. $\mathrm{Tb}$ can also be of high interest for breeders or farmers to choose the suitable cultivation areas according to local temperatures. This indicates how hard it is to get vigorous seed lots that can meet all the criteria assigned to vigor, but these are important in the characterization of genotypes in the selection process.

\section{Materials and Methods}

\subsection{Plant Material}

Experiments were carried out with seeds of 44 sunflower (Helianthus annuus L.) lines corresponding to different genotypes used in sunflower breeding program by SOLTIS (Table S1). They correspond to 21 restorer lines called " $R$ " characterized by small seed size (mean weight of 1000 seeds per $\mathrm{g}(1000 \mathrm{SW})<50)$ and 23 maintainer lines called "B" characterized by large seeds (1000 SW > 50). The 1000 SW were provided by Soltis (Table S1). They were produced in 2014 in the same field in Occitanie, France. Seeds were stored at $20^{\circ} \mathrm{C}$ and $60 \%$ relative humidity (RH) for three months in order to break dormancy and then kept at $10{ }^{\circ} \mathrm{C}$ during the experiment time.

\subsection{Seed Treatments and Germination}

Germination assays were performed in darkness at $20^{\circ} \mathrm{C}$ in $10 \mathrm{~cm}$ petri dishes by placing whole achenes ( 25 per dish, 3 replicates) on a layer of cotton wool moistened with distilled water or with a range of polyethylene glycol (PEG) solutions giving water potential values from -0.4 to $-1.2 \mathrm{MPa}$ [35]. The effect of temperature on germination was also analyzed by placing seeds on water in a range of temperature from 5 to $35^{\circ} \mathrm{C}$. Seed accelerated ageing was performed using $100 \% \mathrm{RH}$ and $45^{\circ} \mathrm{C}$ as storage conditions for $24,72,120$ and $168 \mathrm{~h}$. After ageing, seed germination was evaluated on water at $20^{\circ} \mathrm{C}$ for 10 days. A seed was considered germinated when the radicle had pierced the envelopes (seed coat + pericarp). Germination counts were made daily for 11 to 13 days.

\subsection{Germination Parameter Calculation}

\subsection{1. t50 Calculation}

The time to obtain $50 \%$ germination (t50) was calculated according to the following formula of [36], as modified by [37]:

$$
\mathrm{t} 50=\mathrm{ti}+((\mathrm{N} / 2-\mathrm{ni})(\mathrm{ti}-\mathrm{tj})] / \mathrm{ni}-\mathrm{nj}
$$

where $\mathrm{N}$ is the final number of germinating seeds, and $n j$ and $n i$ are the cumulative number of seeds germinated by adjacent counts at times $t j$ and $t i$, respectively, when $n i<N / 2<n j$. 


\subsubsection{Base Water Potential}

Germination results were analyzed using the hydrotime model described by Bradford [38], which allowed the calculation of the base water potential $\Psi \mathrm{b}$, which corresponds to the minimum $\Psi$ that allows germination [8]. The following equations describe the basis of the hydrotime model:

$$
\begin{gathered}
\Theta H=(\Psi-\Psi b(g)) \times \operatorname{tg} \\
\text { GRg }=1 / \operatorname{tg}=(\mathrm{T}-\mathrm{Tb}) / \Theta \mathrm{T}(\mathrm{g})=(\Psi-\Psi \mathrm{b}(\mathrm{g})) / \Theta H \\
\text { Probit }(\mathrm{g})=(\Psi-(\Theta \mathrm{H} / \mathrm{tg})-\Psi \mathrm{b}(50)) / \sigma \Psi \mathrm{b}
\end{gathered}
$$

where $\Theta H$ is the hydrotime constant (Hydrotime); $\Theta \mathrm{T}(\mathrm{g})$ is the time constant function of temperature permitting radicle emergence of percentage $g$ of seed population; $\Psi$ is the water potential of the water source $(\mathrm{MPa}) ; \Psi \mathrm{b}$ is the base, or minimum, water potential permitting germination $(\mathrm{MPa})$; $\operatorname{tg}$ is time to radicle emergence of germination percentage $g(\mathrm{~h}) ; \mathrm{T}$ is imbibition temperature; $\mathrm{Tb}$ is the minimum temperature allowing radicle emergence; GRg is the germination rate of percentage $g$ of the seed population $\left(\mathrm{h}^{-1}\right) ; \sigma \Psi \mathrm{b}$ is the standard deviation in base water potential within the seed population $(\mathrm{MPa})$.

\subsubsection{Base Temperature}

The minimum or base temperature $(\mathrm{Tb})$ is the lowest $\mathrm{T}$ at which germination can occur [8]. It is calculated using the following formula:

$$
\begin{gathered}
\theta \mathrm{T}(\mathrm{g})=(\mathrm{T}-\mathrm{Tb}) \operatorname{tg}, \text { or GRg }=1 / \operatorname{tg}=(\mathrm{T}-\mathrm{Tb}) / \theta \mathrm{T}(\mathrm{g}) \\
\Theta \mathrm{T}(\mathrm{g})=(\mathrm{T}-\mathrm{Tb}) \times \operatorname{tg} \\
\mathrm{GRg}=1 / \operatorname{tg}=(\mathrm{T}-\mathrm{Tb}) / \Theta \mathrm{T}(\mathrm{g}) \\
\operatorname{Probit}(\mathrm{g})=\log ((\mathrm{T}-\mathrm{Tb}) \times \operatorname{tg})-\log \Theta \mathrm{T}(50) / \sigma \Theta \mathrm{T}
\end{gathered}
$$

where $\Theta \mathrm{T}(\mathrm{g})$ is the time constant function of temperature permitting radicle emergence of $\mathrm{g}$ percentage of the seed population; $\operatorname{tg}$ is the time to radicle emergence of germination percentage $g(\mathrm{~h})$; $\mathrm{T}$ is the imbibition temperature; $\mathrm{Tb}$ is the minimum temperature allowing radicle emergence; GRg is the germination rate of percentage $g$ of the seed population $\left(\mathrm{h}^{-1}\right) ; \sigma \Theta T$ is the standard deviation of the base temperature.

This model predicts that the germination rate for a given seed fraction or percentage $g$ (GRg or $1 / \mathrm{tg}$ ) is a linear function of $\mathrm{T}$ above $\mathrm{Tb}$, with a slope of $1 / \theta \mathrm{T}(\mathrm{g})$ and an intercept on the $\mathrm{T}$ axis of $\mathrm{Tb}$.

\subsubsection{Viability Constant Calculation (Ki)}

Viability constant $(\mathrm{Ki})$ permits one to evaluate the initial quality of a seed lot before the ageing process. The equation of this constant as follows [24]:

$$
v=\mathrm{Ki}-\mathrm{p} / \sigma
$$

where $v$ is viability after $p$ days in storage (probit); $\mathrm{p}$ is the storage period (days); Ki is the seed-lot constant probit percentage viability at the beginning of storage; $\sigma$ is the slope of the line, which shows germination percentage (in probit) function of storage duration.

$\mathrm{Ki}$ is obtained after a probit analysis of a mortality curve of a seed lot obtained after accelerating ageing. This regression analysis follows the mortality frequencies of a seed lot across time (days). Ki is the intercept of the regression with the slope $\mathrm{v}$ with $\mathrm{y}$ axes of a seed lot. 


\subsection{Statistical Analyses}

Matrix correlation calculation, PCA, ANOVA and box plot analyses were performed using FactoMineR package in $\mathrm{R}$ software.

Supplementary Materials: The following are available online at http://www.mdpi.com/2223-7747/9/3/386/s1, Table S1: Genotypes characteristics and constants.

Author Contributions: Conceptualization, H.E.-M.-B. and C.B.; methodology, M.S., C.B. and H.E.-M.-B.; formal analysis, M.S., B.B. and H.E.-M.-B.; resources, T.A. and B.B.; writing-original draft preparation, M.S. and H.E.-M.-B.; writing-review and editing, H.E.-M.-B. and C.B.; supervision, H.E.-M.-B., C.B. and T.A.; funding acquisition, T.A. All authors have read and agreed to the published version of the manuscript.

Funding: This work was supported by Soltis and Association Nationale de la Recherche Technique (ANRT, grant CIFRE $\left.n^{\circ} 2015 / 0174\right)$

Conflicts of Interest: The authors declare no conflict of interest.

\section{References}

1. David, L.D. Chapter 2: Seed Vigor. In Seed Quality. Basic Mechanisms and Agricultural Implications; Food Product Press: Basra, Iraq, 1995; pp. 45-80.

2. Hampton, J.G. What is seed quality? Seed Sci. Technol. 2002, 30,1-10.

3. Ellis, R.H. Seed and seedling vigour in relation to crop growth and yield. Plant Growth Regul. 1992, 11, 249-255. [CrossRef]

4. ISTA Vigour Test Committee. Understanding Seed Vigour. In Handbook of Vigour Test Methods; International Seed testing Association: Zurich, Switzerland, 1995.

5. ISTA Vigour Test Committee. Chapter 15 Seed vigour testing. In International Rules for Seed Testing; International Seed testing Association: Zurich, Switzerland, 2015.

6. Bewley, J.D.; Black, M. Seeds: Physiology of Development and Germination, 2nd ed.; Plenum Press: New York, NY, USA, 1994.

7. Delouche, J.C.; Baskin, C.C. Accelerated aging techniques for predicting the relative storability of seed lots. Seed Sci. Technol. 1973, 1, 427-452.

8. Bradford, K.J. Water relations in seed germination. In Seed Development and Germination; Jaime Kigel and Gad Galili Marcel Dekker Inc: New York, NY, USA, 1995; pp. 351-396.

9. Alvarado, V.; Bradford, K.J. A hydrothermal time model explains the cardinal temperatures for seed germination. Plant Cell Env. 2002, 25, 1061-1069. [CrossRef]

10. Finch-Savage, W.E.; Bassel, G.W. Seed vigour and crop establishment: Extending performance beyond adaptation. J. Exp. Bot. 2016, 67, 567-591. [CrossRef] [PubMed]

11. Nonogaki, H. Seed dormancy and germination emerging mechanisms and new hypotheses. Front. Plant Sci. 2014, 5, 233. [CrossRef] [PubMed]

12. Nonogaki, H. Seed Biology Updates-Highlights and New Discoveries in Seed Dormancy and Germination Research. Front. Plant Sci. 2017, 8, 524. [CrossRef] [PubMed]

13. Gao, F; Ayele, B.T. Functional genomics of seed dormancy in wheat: Advances and prospects. Front. Plant Sci. 2014, 5, 458. [CrossRef] [PubMed]

14. Bazin, J.; Langlade, N.; Vincourt, P.; Arribat, S.; Balzergue, S.; El-Maarouf-Bouteau, H.; Bailly, C. Targeted mRNA Oxidation Regulates Sunflower Seed Dormancy Alleviation during Dry After-Ripening. Plant Cell 2011, 23, 2196-2208. [CrossRef]

15. El-Maarouf-Bouteau, H.; Meimoun, P.; Job, C.; Job, D.; Bailly, C. Role of protein and mRNA oxidation in seed dormancy and germination. Front. Plant Sci. 2013, 4, 77. [CrossRef]

16. Xia, Q.; Ponnaiah, M.; Cueff, G.; Rajjou, L.; Prodhomme, D.; Gibon, Y.; Bailly, C.; Corbineau, F.; Meimoun, P.; El-Maarouf-Bouteau, H. Integrating proteomics and enzymatic profiling to decipher seed metabolism affected by temperature in seed dormancy and germination. Plant Sci. 2018, 269, 118-125. [CrossRef]

17. Xia, Q.; Saux, M.; Ponnaiah, M.; Gilard, F.; Perreau, F.; Huguet, S.; Balzergue, S.; Langlade, N.; Bailly, C.; Meimoun, P. One Way to Achieve Germination: Common Molecular Mechanism Induced by Ethylene and After-Ripening in Sunflower Seeds. IJMS 2018, 19, 2464. [CrossRef] [PubMed] 
18. Hilhorst, H.W.M.; Toorop, P.E. Review on dormancy, germinability and germination in crop and weed seeds. Adv. Agron. 1997, 61, 112-165.

19. Rajjou, L.; Duval, M.; Gallardo, K.; Catusse, J.; Bally, J.; Job, C.; Job, D. Seed Germination and Vigor. Annu. Rev. Plant Biol. 2012, 63, 507-533. [CrossRef]

20. Saux, M.; Ponnaiah, M.; Langlade, N.; Zanchetta, C.; Balliau, T.; El-Maarouf-Bouteau, H.; Bailly, C. A multiscale approach reveals regulatory players of water stress responses in seeds during germination. Plant Cell Environ. 2020, 13731. [CrossRef] [PubMed]

21. Bettey, M.; Finch-Savage, W.E.; King, G.J.; Lynn, J.R. Quantitative genetic analysis of seed vigour and pre-emergence seedling growth traits in Brassica oleracea: RESEARCH QTL analysis of seed vigour in Brassica. New Phytol. 2000, 148, 277-286. [CrossRef]

22. Finch-Savage, W.E.; Clay, H.A.; Lynn, J.R.; Morris, K. Towards a genetic understanding of seed vigour in small-seeded crops using natural variation in Brassica oleracea. Plant Sci. 2010, 179, 582-589. [CrossRef]

23. Morris, K.; Barker, G.C.; Walley, P.G.; Lynn, J.R.; Finch-Savage, W.E. Trait to gene analysis reveals that allelic variation in three genes determines seed vigour. New Phytol. 2016, 212, 964-976. [CrossRef]

24. Ellis, R.H.; Roberts, E.H. Improved equations for the prediction of seed longevity. Ann. Bot. 1980, 45, 13-30. [CrossRef]

25. Balesevic-Tubic, S.; Malencic, D.; Tatic, M.; Miladinovic, J. Influence of aging process on biochemical changes in sunflower seed. Helia 2005, 28, 107-114. [CrossRef]

26. Castillo-Lorenzo, E.; Finch-Savage, W.E.; Seal, C.E.; Pritchard, H.W. Adaptive significance of functional germination traits in crop wild relatives of Brassica. Agric. For. Meteorol. 2018, 264, 343-350. [CrossRef]

27. Belo, R.G.; Tognetti, J.; Benech-Arnold, R.; Izquierdo, N.G. Germination responses to temperature and water potential as affected by seed oil composition in sunflower. Ind. Crop. Prod. 2014, 62, 537-544. [CrossRef]

28. Ambika, S.; Manonmani, V.; Somasundar, G. Review on Effect of Seed Size on Seedling Vigour and Seed Yield. Res. J. Seed Sci. 2014, 7, 31-38. [CrossRef]

29. Moshatati, A.; Gharineh, M.H. Effect of grain weight on germination and seed vigor of wheat. Int. J. Agric. Crop Sci. 2012, 4, 458-460.

30. Zareian, A.; Hamidi, A.; Sadeghi, H.; Jazaeri, M.R. Effect of seed size on some germination characteristics, seedling emergence percentage and yield of three wheat (Triticum aestivum L.) cultivars in laboratory and field. Middle-East J. Sci. Res. 2013, 13, 1126-1131.

31. Ries, S.K.; Everson, E.H. Protein Content and Seed Size Relationships with Seedling Vigor of Wheat Cultivars ${ }^{1}$. Agron. J. 1973, 65, 884-886. [CrossRef]

32. Naylor, R.E.L. The effect of parent plant nutrition on seed size, viability and vigour and on germination of wheat and triticale at different temperatures. Ann. Appl. Biol. 1993, 123, 379-390. [CrossRef]

33. Farahani, H.A.; Moaveni, P.; Maroufi, K. Effect of seed size on seedling vigour in sunflower (Helianthus annuus L.). Adv. Environ. Biol. 2011, 5, 1701-1705.

34. Saranga, Y.; Levi, A.; Horcicka, P.; Wolf, S. Large sunflower seeds are characterized by low embryo vigor. J. Am. Soc. Hortic. Sci. 1998, 123, 470-474. [CrossRef]

35. Michel, B.E.; Kaufmann, M.R. The Osmotic Potential of Polyethylene Glycol 6000. Plant Physiol. 1973, 51, 914-916. [CrossRef]

36. Coolbear, P.; Francis, A.; Grierson, D. The effect of low temperature pre-sowing treatment on the germination performance and membrane integrity of artificially aged tomato seeds. J. Exp. Bot. 1984, 35, 1609-1617. [CrossRef]

37. Farooq, M.; Basra, S.M.A.; Ahmad, N.; Hafeez, K. Thermal hardening: A new seed vigor enhancement tool in rice. J. Integr. Plant Biol. 2005, 47, 187-193. [CrossRef]

38. Bradford, K.J. Applications of hydrothermal time to quantifying and modeling seed germination and dormancy. Weed Sci. 2002, 50, 248-260. [CrossRef]

(C) 2020 by the authors. Licensee MDPI, Basel, Switzerland. This article is an open access article distributed under the terms and conditions of the Creative Commons Attribution (CC BY) license (http://creativecommons.org/licenses/by/4.0/). 